\title{
In situ impact of solar ultraviolet radiation on photosynthesis and DNA in temperate marine phytoplankton
}

\author{
E. Walter Helbling ${ }^{1, *}$, Anita G. J. Buma ${ }^{2}$, M. Karin de Boer ${ }^{2}$, Virginia E. Villafañe ${ }^{1}$ \\ ${ }^{1}$ Estación de Fotobiología Playa Unión, Casilla de Correos No. 153 - (9100) Trelew, Chubut, Argentina and \\ Consejo Nacional de Investigaciones Científicas y Técnicas (CONICET) \\ ${ }^{2}$ Department of Marine Biology, University of Groningen, PO Box 14, 9750 AA Haren, The Netherlands
}

\begin{abstract}
In situ experiments were conducted at various depths in the water column to determine the impact of solar UV radiation (280 to $400 \mathrm{~nm}$ ) upon photosynthesis and DNA of natural phytoplankton assemblages from mid-latitudes of Patagonia (Bahía Bustamante, Chubut, Argentina; $45^{\circ} \mathrm{S}$, $\left.66.5^{\circ} \mathrm{W}\right)$. The effects of UV radiation were significant at the surface; however, the impact decreased rapidly with depth: at $3 \mathrm{~m}$ there was no measurable DNA damage accumulation, whereas at $6 \mathrm{~m}$ photosynthetic inhibition was almost zero. UV-A radiation (315 to $400 \mathrm{~nm}$ ) was mostly responsible for photosynthetic inhibition, while UV-B radiation (280 to $315 \mathrm{~nm}$ ) had a lesser effect on this process. However, UV-B radiation was very effective in damaging the DNA through the formation of cyclobutane pyrimidine dimers (CPDs) in surface waters. The high initial CPD level found in the natural phytoplankton assemblage decreased when samples were incubated at 3 or $6 \mathrm{~m}$, indicating that at these depths repair, dilution or disappearance of damage occurred. Phytoplankton assemblages were dominated by cells less than $2 \mu \mathrm{m}$ in effective diameter; this cell size category seems to be more resistant to photosynthetic inhibition, but vulnerable to CPD accumulation, as compared with larger eukaryotic phytoplankters (i.e., Phaeodactylum sp.).
\end{abstract}

KEY WORDS: UV · Phytoplankton - DNA - CPD · Thymine dimers · Photosynthesis inhibition · Mid-latitudes

\section{INTRODUCTION}

Phytoplanktonic organisms are affected in different ways by ambient levels of solar radiation (HolmHansen et al. 1993a, Häder 1997). In particular, the effects of solar ultraviolet radiation (UVR, 280 to $400 \mathrm{~nm}$ ) in autotrophic organisms have been addressed due to the discovery of the stratospheric ozone depletion (i.e., the ozone 'hole'), as this phenomenon results in an increase of short wavelengths of UV-B radiation (280 to $315 \mathrm{~nm}$ ) reaching the earth's surface (Madronich 1993). One of the most studied effects of solar UVR upon

*E-mail: efpu@efpu.com.ar phytoplanktonic organisms is the inhibition of photosynthetic rates, which has been observed in many regions, such as polar areas (Helbling et al. 1992, Smith et al. 1992, Neale et al. 1998), and temperate (Behrenfeld et al. 1993, Helbling et al. 1993) and tropical environments (Helbling et al. 1992, Behrenfeld et al. 1993, Villafañe et al. 1999). Another effect of UVR that has been particularly addressed in phytoplanktonic organisms is the damage of genetic material (i.e., DNA) as a consequence of the formation of cyclobutane pyrimidine dimers (CPDs), mainly thymine dimers - T<> T (Karentz et al. 1991, Buma et al. 1997, Boelen et al. 1999, unpubl.). Most of the UVR effect studies have been carried out in polar areas (especially Antarctica), as it is thought that organisms of these high latitudes would be 
especially affected by enhanced levels of solar UV-B radiation during springtime ozone depletion events (Smith et al. 1992, Holm-Hansen et al. 1993b, Arrigo 1994). However, as responses to UVR depend on the particular biological, physical and optical characteristics of the ecosystem under study, it is not possible to safely extrapolate the results obtained in polar areas to other aquatic systems of the planet.

There are not many studies that address the impact of solar UVR upon phytoplanktonic species of temperate systems (Behrenfeld et al. 1993, Helbling et al. 1993). In particular, we are not aware of any studies of the effects of solar UVR on phytoplanktonic species of the temperate region of Patagonia in South America. This is rather surprising, considering the high productivity of the coastal areas of Patagonia (Charpy \& Charpy-Roubaud 1980) and the very interesting characteristics that would warrant this type of photobiological study. The mid-latitude aquatic environments of Patagonia, especially the area including the Atlantic coast, receive high daily doses of solar radiation during the austral spring and summer due to a combination of several factors: (1) relatively high irradiances and daylight periods of up to $18 \mathrm{~h}$ (Orce \& Helbling 1997); (2) low cloudiness (Lubin \& Jensen 1995), and (3) clear skies with very low amounts of particles. In addition to these factors, the region is under the influence of periodic events of low column ozone concentrations due to its proximity to the Antarctic polar vortex and the ozone 'hole' (Orce \& Helbling 1997), thus receiving sporadically higher levels of solar UV-B radiation.

This study evaluates the effects of solar UVR upon photosynthesis and DNA in phytoplanktonic species of the Argentinean Sea-Atlantic Ocean, in the area of Bahía Bustamante, Chubut (Patagonia), which is a nutrient rich-high primary productivity region, and commercially important for the collection of the alga Gracilaria verrucosa (Hudson) Papenf. (Rhodophyta). To our knowledge this is the first study that describes in situ UVR effects on photosynthetic performance and, simultaneously, DNA damage induction in marine plankton organisms.

\section{MATERIALS AND METHODS}

This study was conducted at Bahía Bustamante, Chubut ( $\left.45^{\circ} \mathrm{S}, 66.5^{\circ} \mathrm{W}\right)$, Argentina (Fig. 1), during January 1999. Surface water samples were collected early in the morning using acid-cleaned $(1 \mathrm{~N} \mathrm{HCl})$ polycarbonate bottles and incubated in situ $(0,3,6$, and $9 \mathrm{~m}$ depth) for $6 \mathrm{~h}$ centered around local noon (i.e., from 09:00 to $15: 00 \mathrm{~h}$ )

In order to determine the effects of solar UVR on photosynthetic rates, duplicate samples were placed in $50 \mathrm{ml}$ quartz tubes and inoculated with $5 \mu \mathrm{Ci}$ (0.185 MBq) of labeled sodium bicarbonate (Steeman Nielsen 1952). Three different radiation treatments were implemented at each depth: (1) uncovered quartz tubes (samples receiving both photosynthetic available radiation [PAR, 400 to $700 \mathrm{~nm}$ ] and UV), (2) tubes covered with a Mylar-D film, transmitting UV-A (315 to $400 \mathrm{~nm})+$ PAR, and (3) tubes covered with Plexiglas filter UF-3, so that samples received only PAR. The tubes were then placed in aluminum anodized frames that were connected to a buoy, down to the depths mentioned above. After the incubation period, the samples were filtered onto Whatman GF/F filters (25 $\mathrm{mm}$ in diameter), exposed to $\mathrm{HCl}$ fumes overnight, dried and counted using a liquid scintillation counter (Holm-Hansen \& Helbling 1995).

To evaluate the formation of CPDs (i.e., DNA damage) and the potential of repairing DNA, water sam-

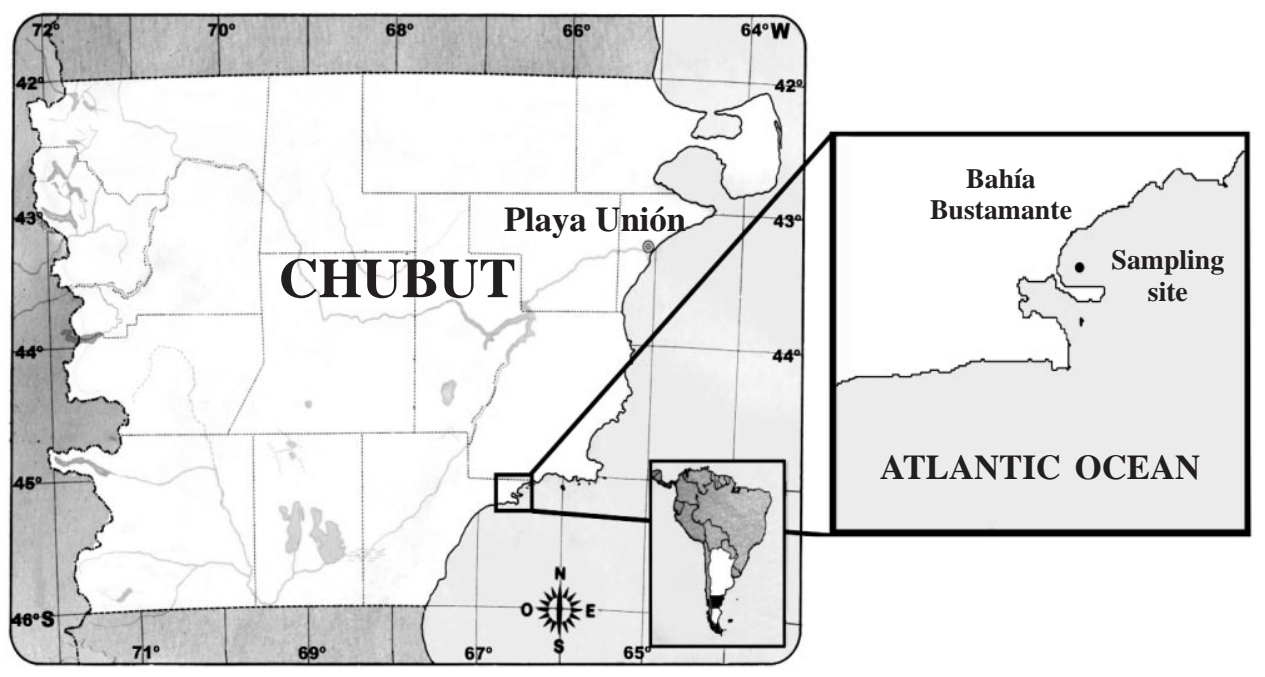

Fig. 1. Map of the Chubut Province, Argentina, indicating the sampling and experimentation site at Bahía Bustamante. Inset: relative location of Chubut in South America 
ples containing natural phytoplankton assemblages were placed in $10 \mathrm{l}$ UV-transparent polypropylene bags hanging next to the aluminum frames. These bags have a very high transparency for all solar wavelengths (Visser et al. 1999). At the start of the experiment $(t=0)$ and after the incubation period, the samples were filtered and fractionated onto 10, 2, and $0.2 \mu \mathrm{m}$ polycarbonate membrane filters (Poretics, $47 \mathrm{~mm}$ ) and immediately frozen in liquid nitrogen $\left(-180^{\circ} \mathrm{C}\right)$ until analyses, which were carried out at the University of Groningen, The Netherlands. DNA was extracted using a modified method from Doyle \& Doyle (1991). Filters were incubated at $60^{\circ} \mathrm{C}$ for $30 \mathrm{~min}$ with $750 \mathrm{\mu l}$ preheated CTAB isolation buffer $(2 \%$ [w/v] CTAB Sigma, 1.4 M NaCl, 0.2\% [v/v] $\beta$-mercaptoethanol, $20 \mathrm{mM}$ EDTA, $100 \mathrm{mM}$ Tris- $\mathrm{HCl} \mathrm{pH}=8.0$ ). An aliquot of $750 \mu \mathrm{l} \mathrm{CIA} \mathrm{(chloroform/isoamylalcohol}$ 24:1) was added to extract the DNA from cell debris and proteins. After centrifugation (14000 rpm $[20000 \times g], 10 \mathrm{~min}), 0.5 \mathrm{ml}$ of cold isopropanol was added to the upper (water) phase to precipitate the DNA $\left(1 \mathrm{~h}\right.$ at $\left.4^{\circ} \mathrm{C}\right)$. After centrifugation $(14000 \mathrm{rpm}$ $[20000 \times \mathrm{g}], 30 \mathrm{~min}$, at $4^{\circ} \mathrm{C}$ ) the supernatant was removed and the pellet was washed with $1 \mathrm{ml}$ of $80 \%$ ice-cold ethanol $\left(15 \mathrm{~min}\right.$, at $-20^{\circ} \mathrm{C}$, followed by centrifugation, $30 \mathrm{~min}$ at $4^{\circ} \mathrm{C}$ ). Finally the DNA pellet was dried under vacuum and resuspended in TE buffer (1 mM Tris- $\mathrm{HCl} \mathrm{pH}=8.0,0.1 \mathrm{mM}$ EDTA). To remove the RNA, the DNA was incubated for $1 \mathrm{~h}$ with $75 \mu \mathrm{g}$ $\mathrm{ml}^{-1}$ RNAse (Boehringer Mannheim) at room temperature. The amount of DNA was determined fluorometrically using Picogreen dsDNA quantitation reagent (dilution 1:400, Molecular Probes) on a 1420 Victor multilabel counter (EG\&G Wallac, excitation $485 \mathrm{~nm}$, emission $535 \mathrm{~nm}$ ).

The amount of CPDs was determined using the method of Boelen et al. (1999, unpubl.), employing a primary antibody directed mainly to thymine dimers. In short, $100 \mathrm{ng}$ of heat-denaturated DNA samples were blotted onto nitrocellulose membranes (Schleicher and Schuell, Protran $0.1 \mu \mathrm{m})$. The membranes were baked at $80^{\circ} \mathrm{C}$ to immobilize the DNA. After a 30 min blocking step, followed by 3 washing steps, the membranes were incubated with the primary antibody $\mathrm{H} 3$ overnight at $4^{\circ} \mathrm{C}$. After repeated washing, incubation with the secondary antibody (HRP rabbit-antimouse, Dako P0260) was done for $2 \mathrm{~h}$ at room temperature. CPDs were detected using ECL detection reagents (RPN2106 Amersham) in combination with photosensitive films (Kodak-X-AR-5). Finally, the films were scanned and the dimers were quantified using Image Quant software (version 4.2, Molecular Dynamics). Each blot contained 2 dilution series of standard DNA with known amounts of CPDs (Boelen et al. 1999, unpubl.). In order to determine DNA effective radia- tion and attenuation, a DNA biodosimeter was used as described in Boelen et al. (1999, unpubl.). Duplicate acid-cleaned quartz tubes, containing bare DNA, were placed close to the polypropylene bags and incubated for the duration of the incubation experiment.

Samples were also taken for analysis of chlorophyll a (chl a), floristic composition and absorption characteristics of phytoplankton. The analyses of these samples were done as follows: (1) chl a analysis: $100 \mathrm{ml}$ of sample was filtered onto a Whatman GF/F filter $(25 \mathrm{~mm}$ in diameter) and the photosynthetic pigments extracted in absolute methanol for $1 \mathrm{~h}$ (Holm-Hansen \& Riemann 1978). Chl a concentration was then calculated from the fluorescence of the extract (Holm-Hansen et al. 1965), using a Turner Designs fluorometer (model TD 700). (2) Samples for identification and enumeration of phytoplankton were placed in $125 \mathrm{ml}$ brown bottles and fixed with buffered formalin (final concentration of $0.4 \%$ in the sample); after settling 25 to $50 \mathrm{ml}$ of sample, they were analyzed with an inverted microscope (Leica DM IL) following the technique described in Villafañe \& Reid (1995).

Incident solar radiation was measured continuously using a broad band ELDONET radiometer (Real Time Computers Inc.), which measures UV-B (280 to $315 \mathrm{~nm}$ ), UV-A (315 to $400 \mathrm{~nm}$ ) and PAR (400 to $700 \mathrm{~nm}$ ) with a frequency of 1 reading $\mathrm{min}^{-1}$. Optical characteristics of the water column were determined using a profiling broad band ELDONET radiometer (Real Time Computers Inc.), which measures UV-B, UV-A, PAR, water temperature and water depth; a total of 6 profiles were done with this sensor. This instrument was deployed by hand from a Zodiak at a site next to our array for in situ incubations

\section{RESULTS}

UV-B radiation decreased with depth in the water column, and the attenuation coefficient $\left(K_{\mathrm{UV}-\mathrm{B}}\right)$ was $0.80 \mathrm{~m}^{-1}$ (Fig. 2A), with the $1 \%$ radiation level found at $5.8 \mathrm{~m}$. The accumulation of CPDs in bare DNA from the biodosimeter was high at $0 \mathrm{~m}$ : 800 CPDs per $10^{6}$ nucleotides. However, DNA effective radiation was so rapidly attenuated that virtually no CPDs could be detected at $3 \mathrm{~m}$. UV-A radiation and PAR penetrated deeper into the water column, with the $1 \%$ radiation level for UV-A at $8.7 \mathrm{~m}$, while the irradiance level for PAR at the bottom (i.e., $15 \mathrm{~m}$ with high tide) was $10 \%$ of the surface irradiance (calculated from $K_{\mathrm{PAR}}$ ). The attenuation coefficients for UV-A $\left(K_{\mathrm{UV}-\mathrm{A}}\right)$ and PAR $\left(K_{\mathrm{PAR}}\right)$ were 0.53 and $0.16 \mathrm{~m}^{-1}$, respectively (Fig. 2B,C). Phytoplankton distribution in the water column was rather homogeneous and no stratification was noticeable from the temperature profile (Fig. 3). Although 


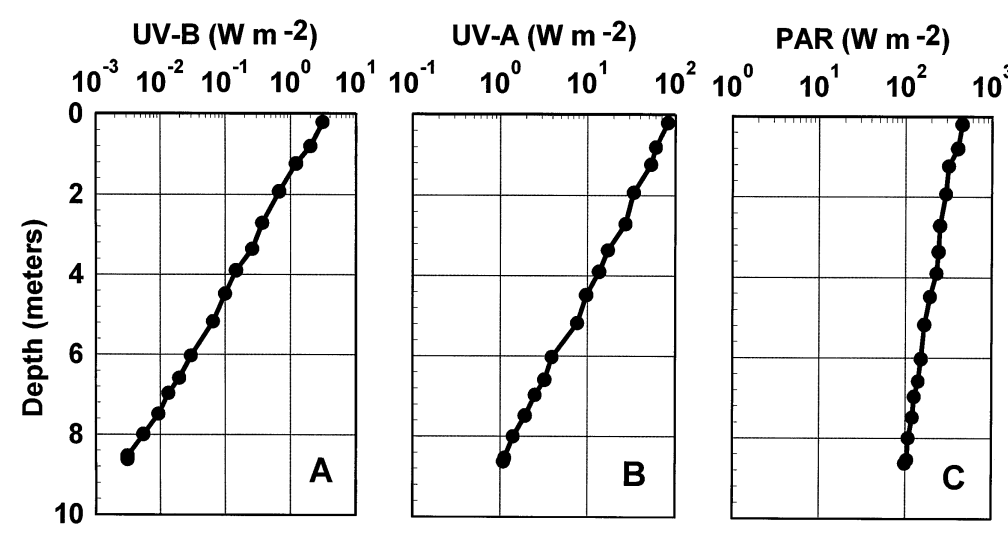

Fig. 2. Representative profiles showing the underwater radiation field next to our in situ experiments; radiation in $\mathrm{W} \mathrm{m}^{-2}$. (A) UV-B radiation; $K_{\mathrm{UV}-\mathrm{B}}=$ $0.80 \mathrm{~m}^{-1}$; (B) UV-A radiation; $K_{\mathrm{UV}-\mathrm{A}}=0.53 \mathrm{~m}^{-1}$; and (C) photosynthetic active radiation $(\mathrm{PAR}) ; K_{\mathrm{PAR}}=0.16 \mathrm{~m}^{-1}$. Profiles done on January 13, 1999 (14:00 h local time)

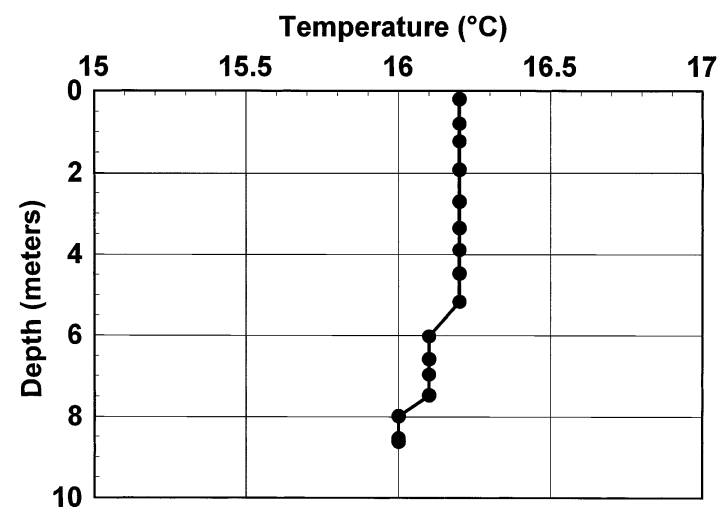

Fig. 3. Water temperature profile $\left(\right.$ in ${ }^{\circ} \mathrm{C}$ ) as a function of depth in waters close to our in situ experiments. Data obtained with

the temperature sensor on the ELDONET radiometer

we did not measure salinity, we estimated that there were no significant changes in the density of the upper part of the water column because there was no input of freshwater into this system. Chl a concentration in the surface sample was $3.1 \mu \mathrm{g} \mathrm{l}^{-1}$. Mean surface incident irradiance values during the time of our experimentation were $2.2,60$ and $450 \mathrm{~W} \mathrm{~m}^{-2}$ for UV$\mathrm{B}, \mathrm{UV}-\mathrm{A}$ and PAR, respectively; the doses during the $6 \mathrm{~h}$ incubation period were 47, 1291 and $9661 \mathrm{KJ} \mathrm{m}^{-2}$ for UV-B, UV-A and PAR, respectively.

Fig. 4 represents the photosynthetic characteristics of natural phytoplankton assemblages when exposed in situ to the 3 radiation treatments mentioned above. The amount of carbon fixed in surface waters during the $6 \mathrm{~h}$ incubation period (Fig. 4A) was about $17.5 \mu \mathrm{g} \mathrm{C}$ $\mathrm{I}^{-1}$ in the treatment that received only PAR. The carbon fixation for PAR was rather constant with depth, hav- ing a very slight increase at 3 to $6 \mathrm{~m}$, suggesting little photoinhibition at the surface due to high PAR levels. The amount of carbon fixed by phytoplankton receiving UV-A + PAR and UV + PAR was 12.6 and $11 \mu \mathrm{g} \mathrm{C}^{-1}$, respectively, and no significant differences $(p<0.05)$ were observed among treatments below $6 \mathrm{~m}$ depth (Fig. 4A). Assimilation numbers (Fig. 4B) were rather constant with depth (about $0.9 \mathrm{mg} \mathrm{C}[\mathrm{mg} \mathrm{chl} \mathrm{a}]^{-1} \mathrm{~h}^{-1}$ ) for the treatment that received only $\mathrm{PAR}$, with maximum numbers found at $3 \mathrm{~m}$. Photosynthetic inhibition (Fig. 4C) at the surface was 29 and $7 \%$ for UV-A and UV-B, respectively, as compared with the treatment that received only PAR. This inhibition decreased with depth so that no significant differences $(p<0.05)$ among treatments were found at $6 \mathrm{~m}$. UV-A was responsible for most of the observed inhibition in the upper water column (i.e., upper $3 \mathrm{~m}$ ).

No DNA could be extracted from the 2 and $10 \mu \mathrm{m}$ fractions, indicating that cells bigger than $2 \mu \mathrm{m}$ represented a negligible proportion of the plankton biomass in terms of DNA. Microscopic observation of phytoplankton samples also revealed that the phytoplankton crop was mainly composed of picoplanktonic cells (less than $2 \mu \mathrm{m}$ in diameter), with very few representatives of larger cells such as diatoms (e.g., Pseudonitzschia spp., Skeletonema costatum, Licmophora sp.). The natural phytoplankton assemblage already had a high level of DNA damage at the time the incubation started, with a mean of $375 \mathrm{~T}<>\mathrm{T}$ per $10^{6}$ nucleotides $(t=0$, Fig. 5B). The high levels of CPDs in the phytoplankton were consistently observed in all morning samples collected for other experiments (data not presented). At the end of the incubation period, the formation of CPDs increased significantly in surface waters (mean value of $650 \mathrm{~T}<>\mathrm{T}$ per $10^{6}$ nucleotides). In contrast, CPD levels at 3 and $6 \mathrm{~m}$ depth diminished to about 250 CPDs per $10^{6}$ nucleotides (Fig. 5B).

\section{DISCUSSION}

Two of the most important physiological forms of natural UVR stress in phytoplanktonic organisms are photosynthetic inhibition and DNA damage. Many studies have evaluated the role of UVR in inhibiting photosynthesis (Helbling et al. 1992, Smith et al. 1992, Neale et al. 1998) and damaging DNA (Karentz et al. 1991, Buma et al. 1997, Boelen et al. unpubl.) in various regions. In this study we considered both targets (i.e., photosynthesis and DNA) at the same time, thus pro- 
viding a powerful tool to evaluate the overall impact of solar radiation in the very productive waters of the Patagonian coast. Our results show that UVR can simultaneously affect photosynthesis and DNA as observed in surface waters (Figs. 4 \& 5).

Phytoplankton photosynthesis in our study was more inhibited by UV-A than by UV-B (Fig. 4), with PAR causing relatively minor photoinhibition. The greater inhibition by UV-A, as compared to UV-B, has also been observed in other freshwater and marine environments (Bühlmann et al. 1987, Kim \& Watanabe 1993, Villafañe et al. 1999). The inhibition of phytoplankton photosynthesis due to solar UVR decreased with depth but was mostly limited to the upper $3 \mathrm{~m}$ of the water column (Fig. 4); below this depth, solar UVR decreased just enough (Fig. 2) to cause a mild effect. In particular, UV-B radiation in our study area (Fig. 2A) had a relatively high attenuation coefficient (i.e., $0.80 \mathrm{~m}^{-1}$ ), as compared to Antarctic areas with similar particle concentration (Helbling et al. 1994). The high $K_{\text {UV-B }}$ in our study most probably reflects the amount of terrigenous material at the coastal station where we conducted the experimentation. However, the attenuation coefficients at Bahía Bustamante were lower than in other coastal areas (Booth \& Morrow 1997). When compared with other environments of Patagonia, such as the sub-Antarctic waters of the Beagle Channel, Tierra del Fuego (Helbling et al. 1996), the total amount of photosynthetic inhibition at the surface was similar at both sites (about 40\%); however, its depth distribution was different (Villafañe et al. 2001). When comparing the overall impact of UVR at these sites, we considered the photosynthetic inhibition as a function of the optical depth (the optical depth of 4.6 is equal to $K_{\mathrm{PAR}}{ }^{*} Z_{\text {eu }}$ ). In the Beagle Channel, photosynthetic inhibition in the water column reached down to 3 optical depths (Helbling et al. 1996, Villafañe et al. 2001), while at Bahía Bustamante it reached down to 1.5 optical depths (Fig. 4C), decreasing almost exponentially. Thus, the depth integrated loss of carbon fixation (upper $10 \mathrm{~m}$ of the water column) due to UV-B (determined when compared to the PAR treatment that was taken as 'no inhibition') would be higher for the Beagle Channel assemblages (calculated value of $24 \%$ ) than for Bahía Bustamante phytoplankton (calculated value of $3 \%$ ). The integrated inhibition at Bahía Bustamante is closer to the $4.9 \%$ value reported for UV-B inhibition in the Antarctic (Holm-Hansen et al. 1993b).

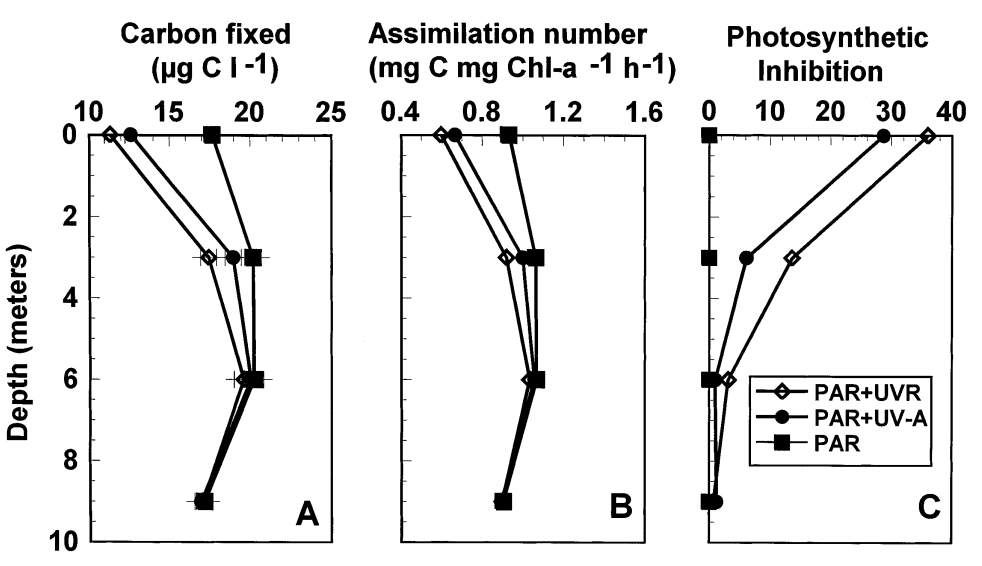

Fig. 4. Depth distribution of (A) carbon fixation, (B) assimilation numbers and (C) percentage of photosynthetic inhibition for natural phytoplankton populations from Bahía Bustamante exposed to 3 radiation treatments; photosynthetic inhibition in the PAR treatment has been set to zero. +: 1 standard deviation

T<>T per 106 nucleotides

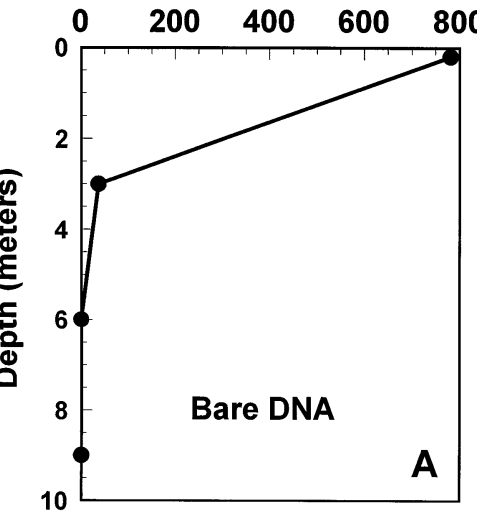

Fig. 5. Depth profiles of CPD formation ( $\mathrm{T}<>\mathrm{T}$ per $10^{6}$ nucleotides). (A) Bare DNA samples, and (B) natural phytoplankton populations. The symbol at $t=0$ indicates the amount of CPDs at the start of the experiment. +: 1 standard deviation
Initial CPD levels were very high in this study (Fig. 5B) and higher than those found in other areas, for instance in marine tropical picoplankton (Boelen et al. unpubl.), in the Antarctic (Buma et al. 2001) or in the plankton from Lake Titicaca, Bolivia (Helbling et al. 2001). This would seem to indicate a prolonged history of previous UV-B exposures in the water column, combined with a low repair capacity of cells. On the other hand, CPD levels decreased at 3 and $6 \mathrm{~m}$ depth, indicating that either repair was taking place, or damage was diluted by de novo DNA synthesis in viable cells. Also, CPD formation may result in an increasing proportion of non-viable cells in the plankton assemblage, eventually leading to a loss of cells from the 
water column through lysis (Boelen et al. unpubl.). It has to be stressed that our CPD results reflect not only picophytoplankton cells but also heterotrophic bacteria, all retained on the $0.2 \mu \mathrm{m}$ filter. However, as has been demonstrated recently by Boelen et al. (1999b), no significant difference in CPD accumulation could be observed in these 2 functional picoplankton groups in tropical marine assemblages. Some studies had determined that small cells (i.e., nanoplanktonic $<20 \mu \mathrm{m}$ in diameter) were generally more resistant than large cells when looking at photosynthetic inhibition (Helbling et al. 1992, Laurion \& Vincent 1998). Simulated in situ experimentation data (not shown), conducted parallel to the in situ studies presented in this paper, were used to calculate the biological weighting function (BWF) for inhibition of phytoplankton photosynthesis. Eight independent experiments were conducted using sharp-cut of filter (Schott); a mean BWF was calculated using a BWF-PI model (Cullen et al. 1992, Neale \& Kieber 2000), and the spectral dependence of the BWF in the broadband intervals was extracted using the method of Rundel (1983). A comparison of Bahía Bustamante BWF with the one for Phaeodactylum sp. (Cullen et al. 1992) showed that phytoplankton from Bahía Bustamante were significantly less sensitive to UVR for wavelengths higher than $300 \mathrm{~nm}$. However, in contrast with this, small cells (less than $2 \mu \mathrm{m}$ ) seem to be more sensitive to UVR when looking at CPD formation (Karentz et al. 1991, Boelen et al. unpubl.). Also, natural Antarctic picoplankton assemblages displayed significantly higher CPD levels compared with larger, diatom-containing size fractions, as a result of exposure to solar UV-B radiation (Buma et al. 2001).

Clearly, CPDs were accumulated in the surface, but no accumulation was observed at 3 and $6 \mathrm{~m}$ depth, in accordance with the strong attenuation of DNA effective UVR (Fig. 5A). It should be considered that cells move in the upper mixed layer (see Fig. 3 for temperature profile) but in an in situ experimentation they are kept at a fixed depth. This means that the surface samples would receive higher irradiance than they would in the upper mixed layer, so an increase in CPDs would be observed. However, the cells incubated at 3 and $6 \mathrm{~m}$ receive less irradiance, thus a decrease in CPDs was noticed (Fig. 5). We have recently shown for plankton organisms from Lake Titicaca (Helbling et al. 2001) that both UV-A and UV-B inhibit photosynthesis, with UV-A having a stronger effect than UV-B. At the same time CPD accumulation was only related with UV-B exposure, as found in this study in Patagonia. Moreover, daily patterns of both photosynthetic inhibition and DNA damage accumulation were far from similar. Evidently, DNA damage accumulation and photosynthetic inhibition patterns reveal effects on various, rel- atively independent cell targets, i.e., nuclear DNA and the photosynthetic apparatus, although interactions between the 2 processes are imaginable (Helbling et al. 2001). Assimilation numbers in our coast reach $5 \mathrm{mg}$ $\mathrm{C}[\mathrm{mg} \mathrm{chl} \mathrm{a}]^{-1} \mathrm{~h}^{-1}$ during the spring bloom, but were lower in the mid-summer post-bloom assemblages (Villafañe, unpub. data). The relatively low assimilation values (about $1 \mathrm{mg} \mathrm{C}[\mathrm{mg} \mathrm{chl} \mathrm{a}]^{-1} \mathrm{~h}^{-1}$ ), compared to the spring bloom, found in this study (Fig. 4), together with the high CPDs values found in the water column, might in fact reveal an interactive process between DNA damage and photosynthetic apparatus.

In conclusion, this study has demonstrated that UV stress may be brought about by multiple target effects, at least at the surface. The extent to which these targets are affected will be determined by irradiance conditions or species-specific differences in vulnerability, for instance related to cell size.

Acknowledgements. We thank M. José, C. Soriano, R. Cariaga and M. Hernández for their help during field work; L. Sala carried out ${ }^{14} \mathrm{C}$ analysis and L. Taibo helped with computer drawings. We also thank the Soriano SA and Fundación Playa Unión for logistic support. We thank the comments of 4 anonymous reviewers. This work was supported by Agencia Nacional de Promoción Científica y Tecnológica, ANPCyT/BID (Project PICT97 07-00000-02206); The Third World Academy of Sciences, TWAS (Project 98-036 RG/ BIO/LA) and Fundación Antorchas (Projects A-13622/1-100 and A13669/1-3). This is Contribution No. 13 of Estación de Fotobiología Playa Unión.

\section{LITERATURE CITED}

Arrigo KR (1994) Impact of ozone depletion on phytoplankton growth in the Southern Ocean: large-scale spatial and temporal variability. Mar Ecol Prog Ser 114:1-12

Behrenfeld M, Hardy J, Gucinski H, Hanneman A, Lee H II, Wones A (1993) Effects of ultraviolet-B radiation on primary production along latitudinal transects in the South Pacific Ocean. Mar Environ Res 35:349-363

Boelen P, Obernosterer I, Vink AA, Buma AGJ (1999) Attenuation of biologically effective UV radiation in tropical Atlantic waters measured with a biochemical DNA dosimeter. Photochem Photobiol 69:34-40

Booth CR, Morrow JH (1997) The penetration of UV into natural water. Photochem Photobiol 65:254-257

Bühlmann B, Bossard P, Uehlinger U (1987) The influence of longwave ultraviolet radiation (u.v.-A) on the photosynthetic activity $\left({ }^{14} \mathrm{C}\right.$-assimilation) of phytoplankton. J Plankton Res 9:935-943

Buma AGJ, Engelen AH, Gieskes WWC (1997) Wavelengthdependent induction of thymine dimers and growth rate reduction in the marine diatom Cyclotella sp. exposed to ultraviolet radiation. Mar Ecol Prog Ser 153:91-97

Buma AGJ, de Boer MK, Boelen P (2001) Depth distributions of DNA damage in Antarctic marine phyto- and bacterioplankton exposed to summertime ultraviolet radiation. $\mathrm{J}$ Phycol (in press)

Charpy LJ, Charpy-Roubaud CJ (1980) La production primaire des eaux du golfe San Jose (Peninsule Valdes, 
Argentine). III. Estimation de la production phytoplanctonique annuelle. Hydrobiologia 75:225-229

Cullen JJ, Neale PJ, Lesser MP (1992) Biological weighting function for the inhibition of phytoplankton photosynthesis by ultraviolet radiation. Science 258:645-650

Doyle JJ, Doyle JL (1991) Isolation of plant DNA from fresh tissue. Focus 12:13-15

Häder DP (1997) Effects of UV radiation on phytoplankton. In Jones JG (ed) Advances in microbial ecology. Plenum Press, New York, p 1-26

Helbling EW, Villafañe VE, Ferrario M, Holm-Hansen O (1992) Impact of natural ultraviolet radiation on rates of photosynthesis and on specific marine phytoplankton species. Mar Ecol Prog Ser 80:89-100

Helbling EW, Avaria S, Letelier J, Montecino V, Ramírez B, Ramos M, Rojas W, Villafañe VE (1993) Respuesta del fitoplancton marino a la radiación ultravioleta en latitudes medias $\left(33^{\circ} \mathrm{S}\right)$. Rev Biol Mar 28:219-237

Helbling EW, Villafañe VE, Holm-Hansen O (1994) Effects of ultraviolet radiation on antarctic marine phytoplankton photosynthesis with particular attention to the influence of mixing. In: Weiler S, Penhale $\mathrm{P}$ (eds) Ultraviolet radiation in Antarctica: measurements and biological effects. Am Geophys Union Antarct Res Ser 62:207-227

Helbling EW, Hernando MP, Holm-Hansen O, Villafañe VE (1996) Efectos de la radiación ultravioleta en el fitoplancton del Canal Beagle, Tierra del Fuego. XVI Jornadas de Ciencias del Mar, Concepción

Helbling EW, Villafañe VE, Buma AGJ, Andrade M, Zaratti F (2001) DNA damage and photosynthetic inhibition induced by solar UV in tropical phytoplankton (Lake Titicaca, Bolivia). Eur J Phycol (in press)

Holm-Hansen O, Helbling EW (1995) Técnicas para la medición de la productividad primaria en el fitoplancton. In: Alveal K, Ferrario ME, Oliveira EC, Sar E (eds) Manual de métodos ficológicos. Universidad de Concepción, Concepción, p 329-350

Holm-Hansen O, Riemann B (1978) Chlorophyll a determination: improvements in methodology. Oikos 30:438-447

Holm-Hansen O, Lorenzen CJ, Holmes RW, Strickland JDH (1965) Fluorometric determination of chlorophyll. J Cons Int Explor Mer 30:3-15

Holm-Hansen O, Lubin D, Helbling EW (1993a) Ultraviolet radiation and its effects on organisms in aquatic environments. In: Young AR, Björn LO, Moan J, Nultsch W (eds) Environmental UV photobiology. Plenum Press, New York, p 379-425

Holm-Hansen O, Helbling EW, Lubin D (1993b) Ultraviolet radiation in Antarctica: inhibition of primary production. Photochem Photobiol 58:567-570

Karentz D, Cleaver JE, Mitchell DL (1991) Cell survival characteristics and molecular responses of Antarctic phyto-

Editorial responsibility: Otto Kinne (Editor),

Oldendorf/Luhe, Germany plankton to ultraviolet-B radiation. J Phycol 27:326-341

Kim DS, Watanabe Y (1993) The effect of long-wave ultraviolet radiation (UV-A) on the photosynthetic activity of natural population of freshwater phytoplankton. Ecol Res 8: $225-234$

Laurion I, Vincent WF (1998) Cell size versus taxonomic composition as determinants of UV-sensitivity in natural phytoplankton communities. Limnol Oceanogr 43: $1774-1779$

Lubin D, Jensen EH (1995) Effects of clouds and stratospheric ozone depletion on ultraviolet radiation trends. Nature 377:710-713

Madronich S (1993) The atmosphere and UV-B radiation at ground level. In: Young AR, Björn LO, Moan J, Nultsch W (eds) Environmental UV photobiology. Plenum Press, New York, p 1-39

Neale PJ, Kieber DJ (2000) Assessing biological and chemical effects of UV in the marine environment: spectral weighting functions. In: Hester RE, Harrison RM (eds) Causes and environmental implications of increased U.V.-B. radiation. Royal Society of Chemistry, Cambridge

Neale PJ, Davis RF, Cullen JJ (1998) Interactive effects of ozone depletion and vertical mixing on photosynthesis of Antarctic phytoplankton. Nature 392:585-589

Orce VL, Helbling EW (1997) Latitudinal UVR-PAR measurements in Argentina: extent of the 'Ozone hole'. Global Planet Change 15:113-121

Rundel RD (1983) Action spectra and estimation of biologically effective UV radiation. Physiol Plant 58:360-366

Smith RC, Prézelin BB, Baker KS, Bidigare RR, Boucher NP, Coley TL, Karentz D, MacIntyre S, Matlick HA, Menzies D, Ondrusek M, Wan Z, Waters KJ (1992) Ozone depletion: ultraviolet radiation and phytoplankton biology in Antarctic waters. Science 255:952-959

Steeman Nielsen E (1952) The use of radiocarbon $\left({ }^{14} \mathrm{C}\right)$ for measuring organic production in the sea. J Cons Int Explor Mer 18:117-140

Villafañe VE, Reid FMH (1995) Métodos de microscopía para la cuantificación del fitoplancton. In: Alveal $\mathrm{K}$, Ferrario ME, Oliveira EC, Sar E (eds) Manual de métodos ficológicos. Universidad de Concepción, Concepción, p 169-185

Villafañe VE, Andrade M, Lairana V, Zaratti F, Helbling EW (1999) Inhibition of phytoplankton photosynthesis by solar ultraviolet radiation: studies in Lake Titicaca, Bolivia. Freshw Biol 42:215-224

Villafañe VE, Helbling EW, Zagarese HE (2001) Solar ultraviolet radiation and its impact on aquatic systems of Patagonia, South America. Ambio (in press)

Visser PM, Snelder E, Kop AJ, Boelen P, Buma AGJ, van Duyl FC (1999) Effects of UV radiation on DNA photodamage and production in bacterioplankton in the coastal Carribean Sea. Aquat Microb Ecol 20:49-58

Submitted: March 22, 2000; Accepted: August 8, 2000

Proofs received from author(s): January 18, 2001 